\title{
PELATIHAN PEMBUATAN MINUMAN BUBUK SECANG BAGI MASYARAKAT SEKITAR UNIVERSITAS PELITA HARAPAN TANGERANG
}

\author{
Ratna Handayani ${ }^{1}$, Hardoko ${ }^{2}$, Wenny S. L. Br Sinaga ${ }^{3}$ \\ ${ }^{1,2,3}$ Program Studi Teknologi Pangan, Universitas Pelita Harapan
}

Email: ratna.handayani@uph.edu,hardoko.fti@uph.edu, wenny.sinaga@uph.edu

\begin{abstract}
Abstrak
Program Studi Teknologi Pangan UPH memiliki visi menjadi salah satu pusat pengembangan teknologi pangan di Indonesia. Pengabdian Kepada Masyarakat yang merupakan salah satu Tridharma Perguruan Tinggi menjadi salah satu sarana untuk mencapai visi tersebut. Masyarakat di sekitar UPH dipilih sebagai mitra guna memperkenalkan minuman bubuk instan secang. Melalui kegiatan ini Program Studi Teknologi Pangan UPH berharap dapat menjalankan misinya yaitu mewujudkan proses pembelajaran di bidang teknologi pangan dengan kualitas yang relevan dengan kebutuhan masyarakat. Kayu secang sering dipergunakan sebagai minuman seduhan dengan penyajian yang tergolong membutuhkan waktu cukup lama. Mengingat masyarakat saat ini yang relatif ingin cepat dalam menyajikan suatu minuman sehingga dengan teknologi yang sederhana dibuat minuman bubuk dengan sifat yang mudah disimpan dan cepat dalam penyajiannya. Produk minuman bubuk instan secang ini dibuat sebagai produk diversifikasi produk pangan. Komponen senyawa bioaktif yang terkandung dalam kayu secang, yaitu brazilin, brazilein, 3'-O-metilbrazilin, sappanone, chalcone, sappancalchone dikenal sebagai antioksidan yang juga berfungsi sebagai pewarna alami pada makanan dan minuman. Penelitian mengenai kayu secang sebagai bahan antioksidan dan pewarna alami sudah banyak dilakukan. Penyuluhan ini diharapkan dapat memberikan wawasan kepada masyarakat di sekitar Universitas Pelita Harapan Karawaci mengenai cara pembuatan minuman bubuk instan secang sehingga dapat membantu meningkatkan taraf ekonomi.
\end{abstract}

Kata Kunci : antioksidan, bubuk, pewarna, secang

\section{PENDAHULUAN}

Berangkat dari salah satu misi program studi Teknologi Pangan UPH yaitu untuk mewujudkan pembelajaran di bidang ilmu dan teknologi pangan yang sesuai dengan kebutuhan masyarakat, maka program program studi Teknologi Pangan melaksanakan kegiatan Pengabdian kepada Masyarakat (PkM). Dengan adanya program ini, diharapkan program studi Teknologi Pangan dapat ikut berperan aktif dalam membantu pengembangan masyarakat sekitar dan berkaitan penting dalam peningkatan kesejahteraan masyarakat melalui aplikasi sains dan teknologi.

Kegiatan pengabdian kepada masyarakat kali ini bertemakan Pelatihan Pembuatan Bubuk Instan Kayu Secang di Masyarakat sekitar UPH, yang ditujukan kepada masyarakat di sekitar UPH dan beberapa staff UPH yang megikuti program pensiun dini, di mana melalui pelatihan ini

$$
\text { Teknologi Tepat Guna }
$$


diharapkan dapat memberikan nilai tambah dalam ekonomi keluarga dengan membuat produk yang memiliki nilai fungsional dan memiliki umur simpan yang relatif cukup lama. Secara umum, kayu secang dikonsumsi oleh masyarakat dengan cara diseduh. Mobilitas masyarakat yang semakin tinggi mendorong pembuatan suatu produk minuman yang memiliki nilai tambah, mudah dan cepat untuk disajikan serta memiliki penampilan yang menarik.

Kayu secang (Caesalpia sappan Linn.) mengandung komponen senyawa bioaktif yaitu brazilin, brazilein, 3'-O-metilbrazilin, sappanone, chalcone, sappancalchone. Komponen bioaktif tersebut merupakan antioksidan yang bermanfaat juga sebagai pewarna alami (Mastuti, et al, 2012) Penelitian mengenai ekstrak kayu secang banyak dilakukan. Dalam kayu secang juga mengandung senyawa terpenoid, fenol. Ekstrak kayu secang mengandung kadar total fenol ekivalen EGC adalah $849,11 \mu \mathrm{g} / \mathrm{mg}$ dan ekivalen ECG 825,11 $\mu \mathrm{g} / \mathrm{mg}$. Ekstrak kayu secang memiliki aktivitas antioksidan tinggi yaitu 80,46-89,13\% (Rina, et al, 2017, Febriyenti, et al, 2018). Selain itu, pigmen alami yaitu brazilin yang terkandung dalam kayu secang dapat berkontribusi memberikan warna merah pada produk makanan dan minuman. Warna merah dari ekstrak kayu secang banyak digunakan untuk membuat minuman tradisional yang dikenal sebagai “wedangsecang”(Widowati, 2011).

Dengan mengetahui proses pembuatan dan manfaat minuman bubuk instan kayu secang yang kaya akan antioksidan, diharapkan tingkat kesadaran masyarakat dalam mengolah kayu secang dan mengonsumsinya dapat ditingkatkan. Berdasarkan paparan di atas, program $\mathrm{PkM}$ ini diharapkan dapat meningkatkan wawasan masyarakat serta meningkatkan taraf ekonomi masyarakat.

\section{METODE}

Langkah-langkah yang dilakukan di dalam kegiatan pengabdian kepada masyarakat meliputi

1. Pembinaan dalam bentuk penjelasan dan presentasi mengenai antioksidan dan pewarna alami:

a. Mengenal antioksidan b. Mengenal pewarna alami

2. Pelatihan dalam bentuk praktek pembuatan bubuk instan kayu secang dan kombinasi dengan penambahan jahe dan sereh :

a. Mengenal tanaman rempah

b. Praktek pengolahan tanaman menjadi bubuk instan yang memiliki karakteristik sensori yang dapat diterima oleh masyarakat

3. Aktivitas umpan balik / tanya jawab mengenai tanaman rempah yang terdapat di pekarangan penduduk sekitar

4. Evaluasi terhadap pelaksanaan pengabdian masyarakat yang mencakup:

a. Kesesuaian kegiatan pelatihan dengan kebutuhan masyarakat

b. Ketercapaian tujuan kegiatan pelatihan dengan masalah yang dihadapi masyarakat

c. Kompetensi dosen/mahasiswa yang membawakan pelatihan

d. Keberlanjutan program PkM

\section{HASIL DAN PEMBAHASAN}

\section{Pemaparan materi}

Pengabdian kepada masyarakat diawali dengan penyampaian materi. Peserta Pengabdian kepada Masyarakat diijinkan untuk berinteraksi dengan memberikan pertanyaan kemudian tim penyuluh dan workshop yang bertugas akan menyampaikan jawaban atas pertanyaan yang muncul. Materi yang disampaikan adalah seputar antioksidan dan pewarna alami serta manfaat dari setiap bahan baku yang dipergunakan dan dilanjutkan dengan cara pembuatan produk minuman. Pada saat pemaparan materi, bahan baku dan produk yang sudah disiapkan sebelumnya dari laboratorium dipresentasikan dan dibagikan kepada peserta, sehingga peserta mengetahui karakteristik yang akan dihasilkan pada akhir dari pelatihan ini. Dengan adanya penyampaian materi, diharapkan dapat membuka wawasan peserta mengenai manfaat kayu secang sebagai sumber antioksidan dan pewarna alami yang aman untuk dikonsumsi. Pada sesi pemaparan juga diberikan informasi mengenai

$$
\text { Teknologi Tepat Guna }
$$


aplikasi penggunaan secang pada minuman secang yang dilengkapi dengan beberapa rempah lainnya yang sangat berkontribusi dalam manfaat, rasa dan penampakan dari minuman secang.

Ketertarikan peserta PkM yang dilaksanakan pada 19 September 2017 ini sudah mulai terlihat sejak sesi pemaparan materi dan semakin nampak pada saat praktek pembuatan produk dengan munculnya banyak pertanyaan dari peserta. Hal ini dapat dilihat pada Gambar 1. Peserta juga ikut berperan aktif dalam kegiatan praktek yang dilakukan secara bergantian. Dari pelatihan ini, peserta juga dijelaskan bagaimana cara untuk melakukan penyeduhan dan jumlah takaran saji yang baik untuk minuman secang jika akan dikonsumsi.

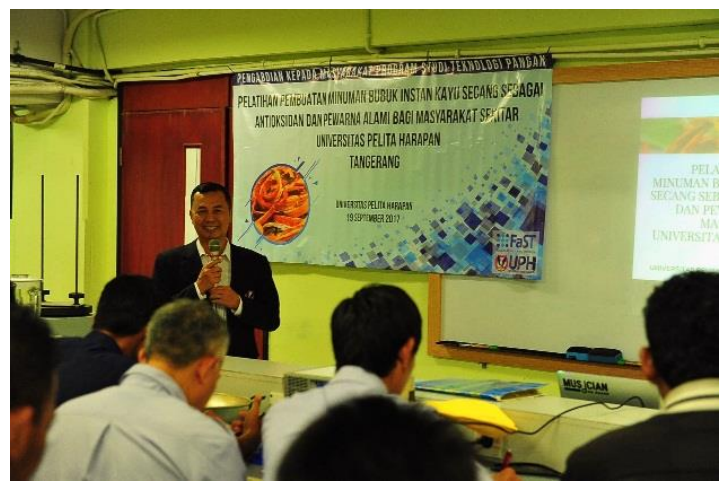

(a)

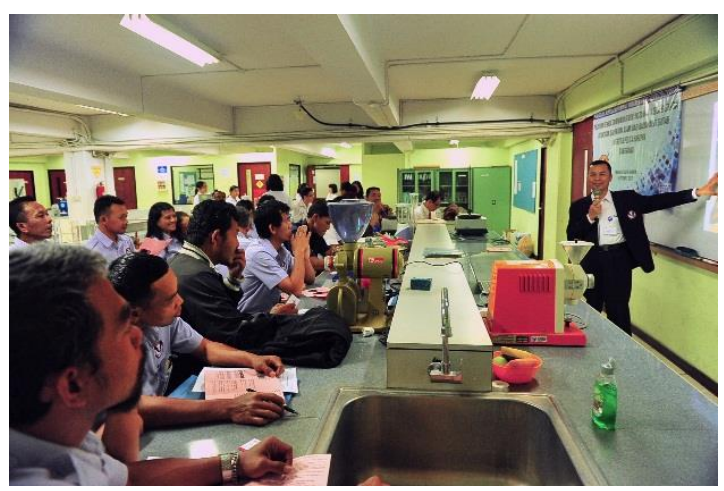

(b)

Gambar 1. Penjelasan materi penyuluhan mengenai antioksidan, bahan baku dan cara pembuatan minuman bubuk secang
Setelah pemaparan materi, peserta melakukan praktek pembuatan minuman serbuk secang. Adapun pembuatan minuman ini diawali dengan pembuatan sari jahe dan air rebusan secang, dilanjutkan dengan pembuatan bubuk kristal minuman bubuk secang dan diakhiri dengan melakukan rekonstitusi bubuk secang yang dihasilkan. Formulasi dan bahan-bahan yang dipergunakan untuk pembuatan minuman bubuk secang dapat dilihat pada Tabel 1.

Tabel 1. Formulasi minuman bubuk secang

\begin{tabular}{cc}
\hline Bahan & Jumlah \\
\hline Air & $500 \mathrm{~mL}$ \\
Jahe & $150 \mathrm{~g}$ \\
Kayu secang & $10 \mathrm{~g}$ \\
Kayu manis & $2 \mathrm{~g}$ \\
Cengkeh & $0,5 \mathrm{~g}$ \\
Kapulaga & $0,35 \mathrm{~g}$ \\
Sereh & 4 batang \\
Gula pasir & $40 \%$ (dari volume air rebusan \\
& secang) \\
\hline
\end{tabular}

Sumber : modifikasi Nurisia, et al, 2018

Pembuatan sari jahe dan sereh dengan menimbang sebanyak 50 gram jahe dan dihancurkan. Selanjutnya menambahkan air sebanyak berat dari jahe yang dipergunakan (1:1) dan dilanjutkan dengan menghancurkannya menggunakan blender. Proses penghancuran tersebut juga dilakukan dengan memasukkan 1 batang sereh. Tahap berikutnya adalah dengan menyaring hasil hancuran tersebut untuk mendapatkan sari jahe dan sereh.

Air rebusan secang dibuat dengan merebus $500 \mathrm{~mL}$ air dan menambahkan sebanyak 100 gram jahe, kayu manis, cengkeh, kapulaga dan 3 batang sereh. Setelah air rebusan mendidih tahap selanjutnya adalah memasukkan kayyu secang dan perebusan dilanjutkan sampai volume cairannya kurang lebih menjadi $300 \mathrm{~mL}$. Atau dapat dilakukan dengan waktu kurang lebih 15 menit menggunakan api yang kecil. Panaskan di dalam penggorengan dengan api yang kecil sampai terbentuk kristal dengan dilakukan pengadukan terus menerus. Kristal 
yang terbentuk diperkceil ukurannya menggunakan blender kering, ayak dan hasil pengayakan merupakan produk minuman bubuk secang.

Pembuatan minuman bubuk secang adalah dengan mencampur sari jahe dan sereh dengan air rebusan secang. Tambahkan gula asir sebanyak $40 \%$ dari volume air rebusan secang.

Bubuk secang yang dihasilkan sebanyak 15 gram dilakukan rehidrasi untuk penyajiannya ke dalam $100 \mathrm{~mL}$ air hangat. Aktivitas peserta dalam pembuatan bubuk secang dapat dilihat pada Gambar 2.

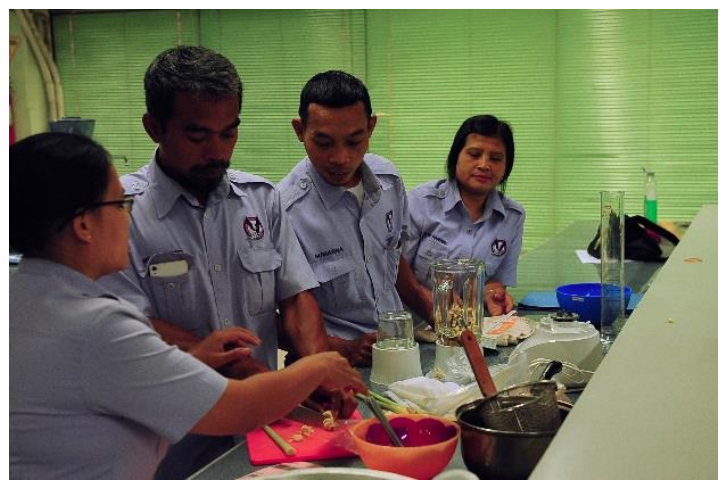

(a)

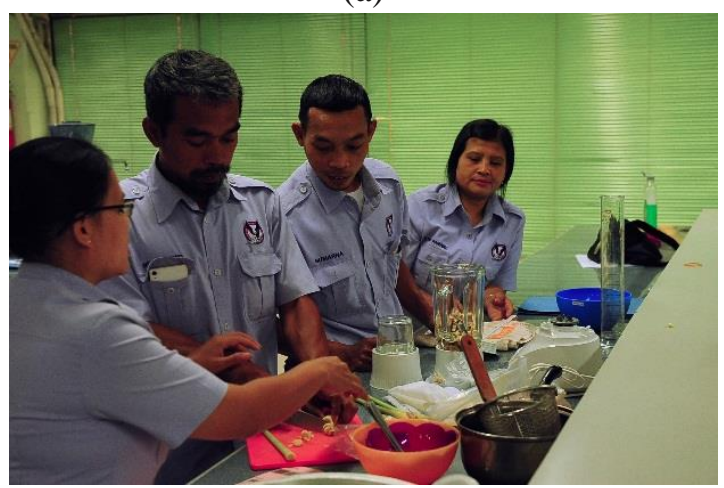

(b)

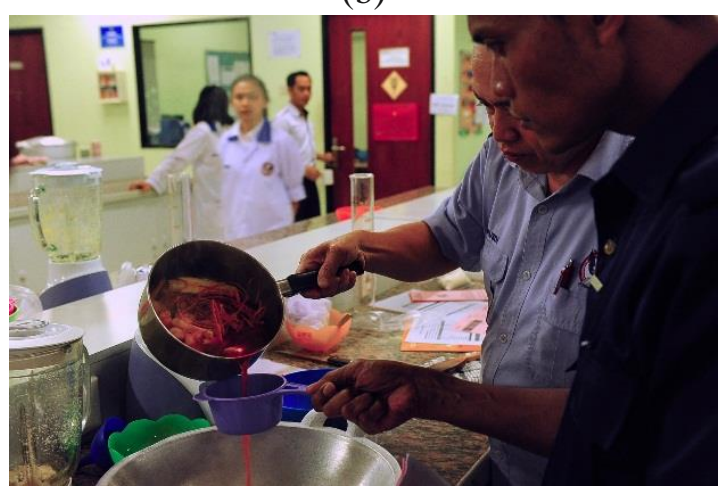

(d)

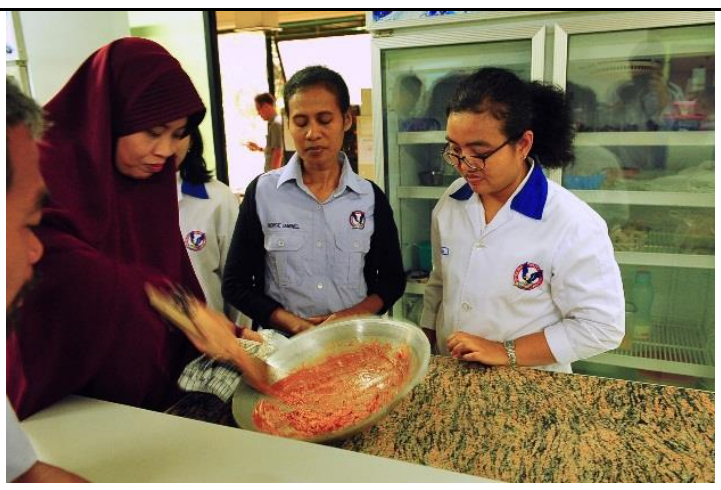

(d)

Gambar 2. Proses pelaksanaan pembuatan minuman bubuk (pembuatan sari jahe-pencampuran dan pembuatan air rebusan secang-pembuatan bubuk kristal)

Bubuk secang yang dihasilkan diperkecil ukurannya dan diayak untuk mendapatkan ukuran butiran kristal yang seragam. Bubuk secang yang dihasilkan oleh peserta dapat dilihat pada Gambar 3.

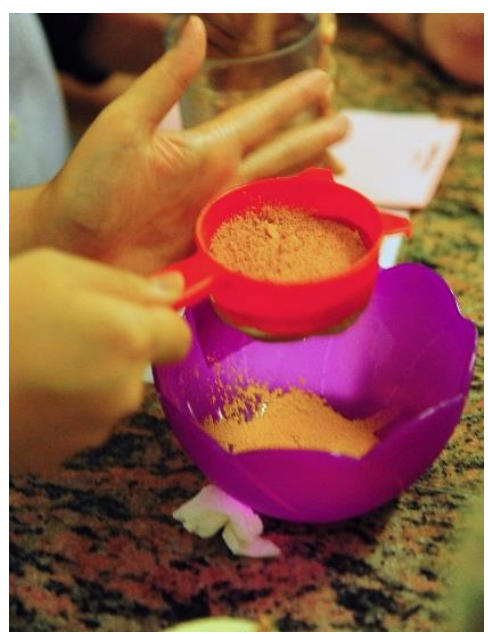

Gambar 3. Minuman bubuk secang

Peserta diberikan contoh bagaimana cara perhitungan supaya didapatkan harga jual minuman bubuk secang sehingga didapatkan titik impas atau Break Even Point (BEP). Berikut adalah contoh perhitungan untuk BEP dengan asumsi satu kali produksi menghasilkan $1 \mathrm{~kg}$ bubuk instan dengan takaran saji 15 gram bubuk secang dalam $100 \mathrm{~mL}$ air hangat. Atau dengan kata lain dalam satu produksi

Teknologi Tepat Guna 
dilakukan perkiraan dapat menghasilkan 600 cup minuman secang.

Total biaya tetap dan biaya variable dapat dilihat pada Tabel 2 dan 3 .

Tabel 2. Biaya Tetap (peralatan)

\begin{tabular}{|c|c|c|c|}
\hline Peralatan & \multicolumn{2}{|c|}{$\begin{array}{c}\text { Jumlah } \\
\text { (buah) }\end{array}$} & $\begin{array}{c}\text { Harga } \\
\text { (Rp) }\end{array}$ \\
\hline Kompor \& Gas & 1 & & 350.000 \\
\hline Pisau & 2 & & 30.000 \\
\hline Talenan & 1 & & 35.000 \\
\hline Panci kecil & 1 & & 40.000 \\
\hline Penggorengan & 1 & & 25.000 \\
\hline Gelas ukur & 1 & & 13.000 \\
\hline Pengaduk & 1 & & 20.000 \\
\hline Blender & 1 & & 00.000 \\
\hline Ayakan teh & 1 & & 20.000 \\
\hline Sendok & 1 & & 5.000 \\
\hline Mangkuk kecil & 1 & & 15.000 \\
\hline Timbangan & 1 & & 60.000 \\
\hline \multicolumn{2}{|c|}{ TOTAL } & \multicolumn{2}{|c|}{1.413 .000} \\
\hline \multicolumn{4}{|c|}{ Tabel 3. Biaya Variabel } \\
\hline Bahan & $\begin{array}{l}\text { Jumlah } \\
\text { gram/buah) }\end{array}$ & $\begin{array}{c}\text { Harga } \\
\text { per } \\
\text { gram }\end{array}$ & $\begin{array}{l}\text { Harga } \\
(\mathrm{Rp})\end{array}$ \\
\hline $\begin{array}{c}\text { Kayu } \\
\text { secang }\end{array}$ & 100 & 36 & 3.600 \\
\hline Kayu Manis & 20 & 125 & 2.500 \\
\hline Gula & 1000 & 16 & 16.000 \\
\hline Kapulaga & 10 & 100 & 1.000 \\
\hline Cengkeh & 6 & 500 & 3.000 \\
\hline Jahe & 1200 & 60 & 72.000 \\
\hline Air Mineral & 10 & 2.500 & 25.000 \\
\hline \multirow[t]{2}{*}{$\begin{array}{c}\text { Kemasan } \\
\text { (cup) }\end{array}$} & 60 & 675 & 40.000 \\
\hline & TOTAL & & 163.600 \\
\hline
\end{tabular}

Berdasarkan Tabel 2 dan Tabel 3 total biaya yang diperlukan adalah Rp 1.576.000. Dan dari biaya tetap dan biaya variable menurut rumus BEP didapatkan nilai BEP pada Rp 2.592.000.

\section{Hasil kuesioner}

Secara keseluruhan, acara berlangsung dengan baik, lancar dan mendapatkan respon positif dari para peserta penyuluhan ini. Hal ini dapat dilihat pada hasil kuesioner yang dibagikan setelah selesai diadakannya pengabdian kepada masyarakat.

Berdasarkan hasil evaluasi pada Tabel 2, terlihat bahwa peserta PkM memberikan respon yang baik terhadap kegiatan yang dilakukan. Sebanyak $88 \%$ peserta belum pernah mengikuti PkM dengan topik yang sejenis dan sekitar 92\% menyatakan bahwa topik yang dibawakan menarik dan menambah wawasan. Peserta juga merasa bahwa kegiatan PkM ini berguna untuk mereka, penyuluh memberikan informasi dengan baik dan juga media yang digunakan sangat mudah dimengerti.

Hasil kuesioner ini menunjukkan bahwa kegiatan PkM dalam bentuk penyuluhan dan pelatihan singkat dapat dilakukan lagi dikemudian hari. Sebagian besar perserta (88\%) ingin mencoba dan menyampaikan informasi ini kepada orang lain. Beberapa respon negatif yang ada akan menjadi bahan evaluasi bagi tim PkM program studi Teknologi Pangan, sehingga, materi kegiatan PkM ini dapat terus ditingkatkan oleh Tim PkM Program Studi Teknologi Pangan.

\section{KESIMPULAN}

Kegiatan PkM dengan judul "Pelatihan Pembuatan Minuman Bubuk Kayu Secang Sebagai Antioksidan dan Pewarna Alami Bagi Masyarakat Sekitar Universitas Pelita Harapan" telah dilaksanakan dengan baik sesuai dengan perencanaan yang telah dilakukan. Kegiatan penyuluhan ini diikuti oleh 26 orang dari masyarakat sekitar UPH serta 10 orang tim penyuluh PkM yang terdiri dari 6 dosen dan 4 mahasiswa/i.

Bentuk kegiatan dari PkM ini adalah penyuluhan, praktik pembuatan minuman bubuk serta tanya jawab. Antusiasme dan partisipasi aktif para peserta sangat mendukung keberlangsungan program ini. Diharapkan dengan kegiatan PkM ini, para peserta dapat melihat potensi dari kayu secang serta rempah-rempah lainnya untuk diaplikasikan dalam berbagai produk pangan yang dapat membantu peningkatan ekonomi peserta PkM.

$$
\text { Teknologi Tepat Guna }
$$




\section{UCAPAN TERIMAKASIH}

Ucapan terimakasih disampaikan kepada LPPM UPH yang telah memberikan kontribusi dalam pelaksanaan kegiatan.

\section{REFERENSI}

Febriayenti, Suhartati, N., Lucida, H., Husni, E., dan Sedona, O. Karakterisasi dan Studi Aktivitas Antioksidan dari Ekstrak Etanol Secang (Caesalpinia sappan L.). Jurnal Sains Farmasi \& Klinis. Vol 5 No. 1:23-27. 2018

Mastuti E., Kim E. V, Christanti, M. E. Komponen senyawa bioaktif yang terkandung dalam kayu secang, yaitu brazilin, brazilein, 3'-Ometilbrazilin, sappanone, chalcone, sappancalchone. Ekuilibrium. Vol. 11 No.1: 1-5. 2012

Nutrisia, A. S., Dewi, I. K., Rusita, Y.D., Pengembangan Formula Wedang Secang sebagai
Minuman Kemasan Rendah Kalori. Jurnal Terpadu Ilmu Kesehatan. Vol 7. No 1: 87-95. 2018

Rina O., Sanusilbrahim, AbdiDharma, Afrizal, Utami C., dan Widodo Y.R. Stabilities natural colorant of Sappan wood (Caesalpinia sappan. L) for food and beverages in various $\mathrm{pH}$, temperature, and matrices of food. International Journal of ChemTech Research Vol. 10 No.1: 098103. 2017.

Widowati W. Uji Fitokimia dan Potensi Antioksidan Ekstrak Etanol Kayu Secang (Caesalpinia sappan L.). Jurnal Kedokteran Maranatha. Vol. 11 No. 1: 23-31. 2011 